\title{
Queer läsning av romance
}

Abrahamsson, Elin Enahanda läsning: En queer tolkning av romancegenren (diss.). Ellerströms 2018 (286 sidor)

ROMANCE ÄR EN benämning som de senaste åren importerats från den anglosaxiska världen som en beteckning på en typ av populära kärleksberättelser med lyckliga slut. En framgångsrik genre som ofta nedvärderas och beskrivs som avskyvärd, dålig litteratur, som "skräp" och "porr" för medelålders kvinnor. Genren beskrivs på ett förvånansvärt likartat sätt även från feministiskt håll som ofta ser den som heteronormativ och/ eller antifeministisk. Hur kommer det sig, frågar Elin Abrahamsson,

att samma texter som anses reproducera en könskonservativ heterosexism är föremål för en misogynt laddad kritik? Och hur kommer det sig att den feministiska kritiken mot genren så ofta använder sig av samma vokabulär som den misogyna kritiken? (Abrahamsson 2018, I7)

Syftet med avhandlingen är både att undersöka vilka förståelser av genus och sexualitet som framträder i den nedvärderande synen på romancegenren och att studera hur dessa förståelser avviker från och utmanar en kulturellt premierad och normativ sexualitet. Avhandlingens teoretiska utgångspunkter är hämtade från fältet feministiska kulturstudier och queerteori, med rötter hos Judith Butler och Eve Kosofsky 
Sedgwick, men också queer temporalitet som den utvecklats av bland andra Sara Ahmed och Elisabeth Freeman. Materialet är E. L. James Fifty Shades of Grey-triologi (2OI I-2OI 2, på sv. Femtio nyanser av honom) och Stephanie Meyers Twilightsaga på fyra romaner (2005-2008), inklusive filmatiseringarna som gjorts på böckerna. Valet av dessa i stället för Harlequinböcker, som ofta är vad som främst förknippas med genren romance, är den uppmärksamhet och kritik som de rönt i svenska och internationella medier i kombination med deras omåttliga popularitet. Som Abrahamsson visar uppfyller materialet konventionerna för romancegenren. Ett brett textbegrepp gör det också möjligt att tolka inte endast böckerna och filmerna utan även hela den kringvärld av produkter med allt ifrån underkläder och anteckningsböcker till workshops om att skriva romance i samma stil.

Kapitel två fokuserar den nedvärderade synen romancegenren och dess historia. Avhandlingen argumenterar för att den tidigare forskningen kan delas in två riktningar, dels studiet om romance under tidigt I980-tal utifrån Janice Radway, som var kritisk mot texterna, dels romancestudier som centreras mer kring litterär analys än på läsare och industri och därför är mer positivt inställda till texterna. Spänningen mellan de två fälten har gjort att den nutida romanceforskningen undvikit att engagera sig i kritiska feministiska kulturstudier, menar Abrahamsson.

En avgörande teoretisk startpunkt för avhandlingen har varit Kosofsky Sedgwicks artikel "Jane Austen and the Masturbating Girl", en tolkning av den romanläsande Marianne Dashwood som en onanist. Fokuseringen på onani som förståelsemodell för läsningen utvecklas i tredje kapitlet där de svenska mediakommentarerna på Femtio nyanser av honom och Twilight studeras. Med stöd i Thomas Laqueurs Solitary Sex: A Cultural History of Masturbation (2003) lyfter Abrahamsson fram likheterna mellan idéer om farorna med onani och (kvinnors) läsning. Fenomenen inte bara sammanfaller i västerländsk kulturhistoria utan de påminner också om varandra i det hot som de tycks utgöra för samhällsorganisationen. Problemet är att kvinnorna som är absorberade av den romantiska fiktionen kanske är totalt oberoende av de män som iakttar 
och kommenterar dem. Romanceläsaren, liksom onanisten, kan sägas förkroppsliga möjligheten till sexuell självförsörjning.

I det följande kapitlet diskuteras själva läsakten och vilka betydelser som uppstår när läsakten förstås som ett slags onani. I romancegenren etableras ett onanistiskt kontinuum där gränserna blir suddiga mellan läsaren och andra kvinnor - författare och hjältinnor - och där positioner, relationer och identifikationer pendlar, rör sig och byter plats. Romanceläsarna verkar lika mycket åtrå hjältinnorna och författarna som de feminint kodade texter de läser. Det onanistiska kontinuumet antar därmed två betydelser, dels ett separatistiskt kvinnorum i vilket kvinnor ensamma är förmögna att ge varandra omsorg och njutning, dels ett autoerotiskt rum där romanceläsaren - som både är hjältinna och författare - är självtillräcklig.

I förlängningen av sin analys definierar Abrahamsson tre nivåer - läsningen, rummet och skrivandet - som hon menar ska förstås snarare som en eskapistisk tillflykt än flykt. Om läsningen förstås som en sexuell handling så innebär den en än mer långtgående protest mot just den påbjudna heterosexualitetens förtryck. I den onanistiska läsningen ger den läsande kvinnan sig själv kontroll över sin egen känslomässiga och sexuella njutning - hon kan ge sig själv den, när hon vill, hur hon vill och hur mycket hon vill.

I närläsningar visar sedan Abrahamsson att det faktiskt är till kroppen genren talar. Genom en fokusering på läsningens här och nu, det vill säga en förståelse av läsarens möte med texten som ett tidsligt avgränsat och sexuellt genomsyrat rum, visas hur romancegenren utnyttjar alla upptänkliga former av sinnlighet för att väcka njutning. I Twilight tillåts den feminint kodade blicken hos hjältinnan styra det filmiska skeendet. Ögonen etablerar inte bara hjältens utseende och personlighet, utan framför allt avslöjar de hans reaktion på hjältinnan. Både Edward och Christian Grey blickar tillbaka på hjältinnan. Då hon söker hjältens blick kan hon också sägas erotisera sin egen begärlighet. Hjältinnan, menar Abrahamsson, intar således en begärsposition som kan beskrivas som både aktiv och passiv, som både begärande och begärd. Maskulina och feminina begärspositioner aktiveras alltså samtidigt och gränserna mellan dem överskrids. 
Abrahamsson menar vidare att romance här skiljer sig från pornografi, vars ramberättelse gör ögonblicket så explicit att det är omöjligt att ompröva dess betydelse, romanceberättelsen ger i stället möjlighet och tillåtelse att gå in i de frysta ögonblicken på ett "säkert" sätt. Förstapersonberättandet, till skillnad från de äldre Harlequinromanernas tredjepersonsperspektiv, möjliggör denna förvandling av allt till erotiska sensationer där romanen ständigt lyckas frysa berättelsens föde till förmån för ögonblick av erotisk kontemplation.

I det avslutande kapitlet drar Abrahamsson ihop trådarna och konstaterar att texternas subversiva potential delvis omintetgörs av texterna själva. Den autoerotiska och homoerotiska blick som identifierats i den onanistiska läsningen verkar til syvende og sidst behöva hjältens manligt och heterosexuellt kodade blick som en form av heteronormaliserande alibi för att låta sig göras. Trots detta framstår texternas homoerotiska, autoerotiska och onanistiska element delvis som en förklaring till den kulturella hotbild som ruvar i romancegenren. Det är också därför, hävdar hon, som kritiken riktar sig mot just den onanistiska läsaren och läsningen. Romancegenren representerar ett annat slags motstånd än det som vanligtvis förknippas med politisk protest, såsom krav på makt, representation och inflytande. Det är genom sin överdrivenhet, sin excess, ett slags kvinnlig grotesk. Romanceläsaren representerar hotbilden av den normativa femininitetens överdrift, skriver hon. Abrahamssons slutsats är att det hot som romanceläsaren, i likhet med onanisten, representerar är en ovilja att erkänna det heterosexuella spelets regler eftersom hon faktiskt kan strunta i att delta.

Enahanda läsning är en välskriven bok. Genredefinitionerna i början kunde dock ha kortats ned till förmån för de intressanta läsningarna som litteraturvetare hade jag gärna sett att fler aspekter av verken hade kunnat utvecklas i analysen. Ingången med onani blir som mest givande i den kulturhistoriska jämförelsen och delvis i själva läsningarna. Här finns dock en glidning mellan de olika betydelsenivåerna av onani, som kulturhistorisk kontext, som funktion för läsningen och som en bild av vad som händer i texterna och i läsarens tolkning av dem - en glidning som aldrig riktigt tydliggörs eller problematiseras. Men oftast fungerar 
det bra, framför allt i analysen av kvinnorna runt organisationen Romance Writers, och i närläsningarna när Abrahamsson visar hur böckernas förstapersonsperspektiv bidrar till möjligheter för läsaren att både identifiera sig med och begära den kvinnliga huvudpersonen. Slutsatsen att romanceläsaren inte flyr från utan till, att hon därför väljer sin egen njutning och därmed helt avvisar frågan om högt och lågt, ger ändå ett nytt - och feministiskt - perspektiv på romancegenren.

\section{CLAUDIA LINDÉN SÖDERTÖRNS HÖGSKOLA}

